\title{
Housing the Elderly in South West England
}

In: Espace, populations, sociétés, 1987-1. Personnes âgées et vieillissement - Elderly people and ageing - Londres, juillet 1986. pp. 207-218.

\begin{abstract}
The spatial distribution of elderly persons in S.W. England will be discussed, with special reference to the South Hams District of Devon. Housing problems presented by the very high concentration of the elderly in this area, in particular those aged $75+$ will be assessed in relation to local and county planning policies. The relationship between the elderly and the local housing market provides the major focus for this paper. The changing geography of the elderly in relation to housing provision may be interpreted in two main ways: either the housing market may be viewed as one that is responding to increasing demands from the growing population; or the provision of speculative housing supply may itself be a determinant of these new spatial patterns at the local scale.
\end{abstract}

\section{Résumé}

Le logement de la population âgée dans le sud-ouest de l'Angleterre.

La distribution géographique des personnes âgées est décrite, avec référence particulière au South Hams District dans le comté du Devon. Des problèmes de logement provenant de la concentration très marquée des personnes âgées dans ce district, des 75 ans et plus en particulier, sont évalués en tenant compte des projets des autorités locales et de l'administration du comté. Le rapport entre les personnes âgées et le marché du logement est le sujet principal de cette étude. En ce qui concerne la disponibilité du logement, il existe deux interprétations possibles : soit le marché obéit à la demande croissante d'une population toujours plus grande; soit $\mathrm{V}$ offre spéculative de logement est une cause des tendances nouvelles géographiques sur le plan local.

Citer ce document / Cite this document :

Winchester Hilary P.M., Grafton David J., Smith John R. B. Housing the Elderly in South West England . In: Espace, populations, sociétés, 1987-1. Personnes âgées et vieillissement - Elderly people and ageing - Londres, juillet 1986. pp. 207218.

doi : 10.3406/espos.1987.1193

http://www.persee.fr/web/revues/home/prescript/article/espos_0755-7809_1987_num_5_1_1193 
Hilary P.M. WINCHESTER

David J. GRAFTON

John R.B. SMITH
Department of Geographical Sciences

Plymouth Polytechnic, United Kingdom

\section{Housing the Elderly in South West England*}

\section{INTRODUCTION}

This paper is concerned with the changing geography of the elderly in the South West Region of England, and the relationship between the housing market and the growth and distribution of the elderly population. The housing market is a major element of the geography of the elderly which has been relatively little studied until recent years (Taylor and Todd, 1982). Private residential care is, however, only a small element in housing provision for the elderly, despite its increasing importance. The housing market for the elderly, as for other migrant groups, is extremely segmented, and is both growing very rapidly.

This study aims, first, to examine the growth and distribution of the elderly at a variety of scales in the South West; in so doing it focusses particularly on two coastal districts of south Devon; Torbay, a traditional resort area self-styled as the
"English Riviera", and the South Hams, a picturesque and less-developed rural area between Torbay and Plymouth. Secondly, the retirement migration and distribution of the elderly is related to the housing market and to the planning framework within which residential development is constrained. The provision of residential accomodation has traditionally been viewed as a function of demand by relatively wealthy retirees, who have tended to move into the area from more expensive housing areas, principally from the South East Region. However, the evidence from south Devon indicates that the activities of housing developers and of the owner-managers of residential homes have become increasingly significant in determining the residential geography of the elderly, as has the control over accomodation supply exerted by relevant authorities.

* Some of the research reported in the paper was undertaken with the benefit of a Devon County Council short term research assistantship. We are grateful to Brian Rogers for drawing the maps. 


\section{THE ELDERLY POPULATION IN SOUTH WEST ENGLAND: DISTRIBUTION AND TRENDS}

\section{Spatial distribution}

On of the most striking features of the distribution of the elderly in Britain is its degree of concentration at the inter- and intra-regional scales. Inter-regionally, the highest proportion of elderly persons is found in South West England: 21 percent against a national average of 18 percent in 1981. Other Regions with sizeable elderly populations include East Anglia (19\%) and Wales (18\%) (Warnes and Law, 1984). The South West has long been a popular retirement area, combining physical qualities of mild climate, picturesque scenery and above all the attraction of the coast (Law and Warnes, 1976).

The countries of Cornwall, Devon, Dorset and Somerset all contain proportions of the elderly in excess of the national average. At the smaller, county district (CD) scale there are some extreme examples of elderly still above the national average. In the county of Devon, the number of persons over retirement age increased by 218000 $(+10 \%)$ between 1971 and 1981 , whereas in the previous decade the proportion had risen by 23 percent. This pattern has occurred also at the District level for the South Hams and East Devon, but in the traditional retirement resort of Torbay, the elderly population actually decreased slightly between 1971 and 1981 .

The increasing numbers of those aged 75 and over years percent is of special interest. In the South West this group accounted for 6 percent of the total population in 1981, yet in Devon the proportion was 8 percent. This figure represented an increase of some 13000 persons $(+21 \%)$ in ten years. This rapid growth rate is even more pronounced at the local level: South Hams CD for

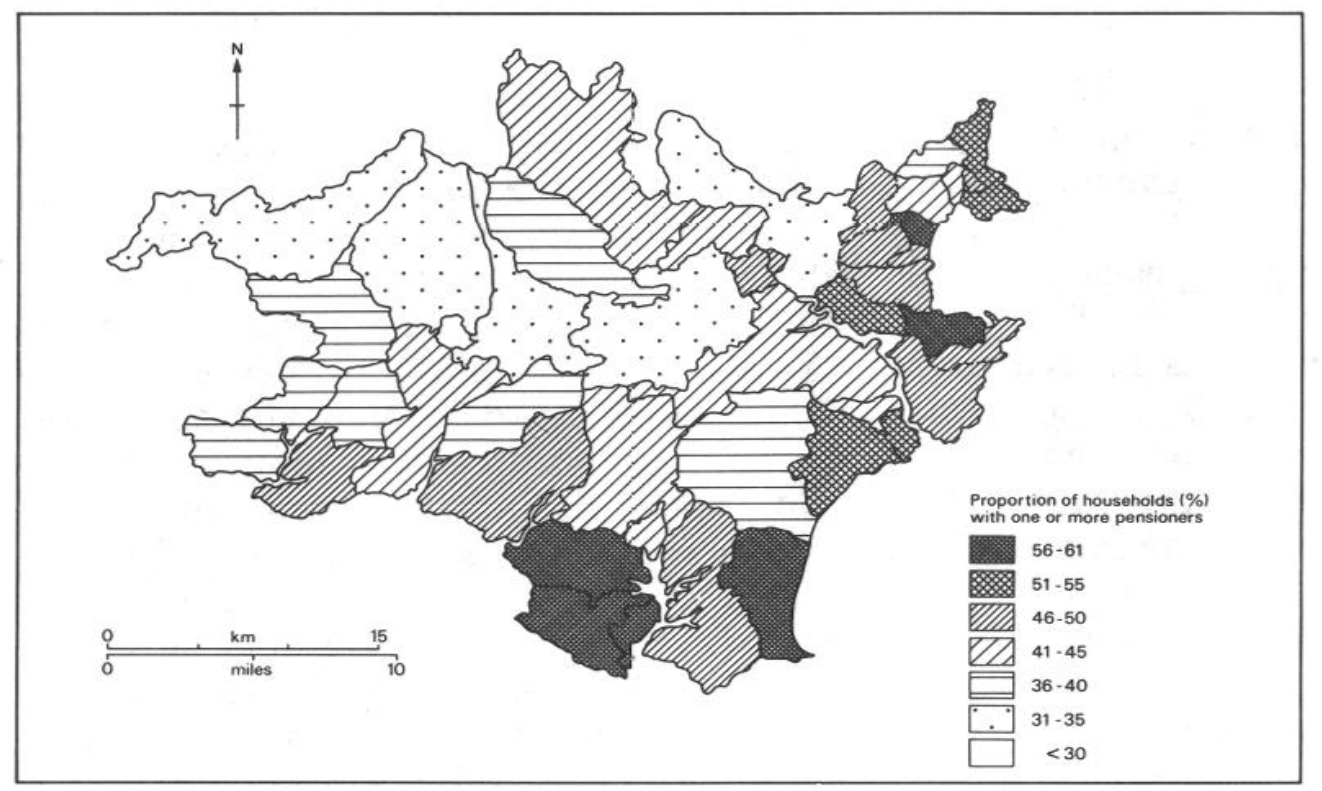

Figure 1.

Distribution of pensioner households in South Hams and Torbay Districts, South Devon, England, 1981. concentrations, particularly in coastal areas. 31 percent of East Devon CD's population was over retirement age in 1981, while in south Devon Torbay CD and South Hams CD recorded figures of 29 percent and 24 percent respectively.

\section{Temporal change}

The rate of growth of the elderly population in South West England has been slowing down in recent years, although it is example recorded a 32 percent increase in this group 1971-81.

The south Devon study area

The focus of this paper is the relationship between the elderly and the housing market in those coastal areas of south Devon where the elderly are most highly concentrated. South Hams and Torbay CDs were analysed using small-area statistics from the 1981 census. These areas were chosen because of their high proportion of the 

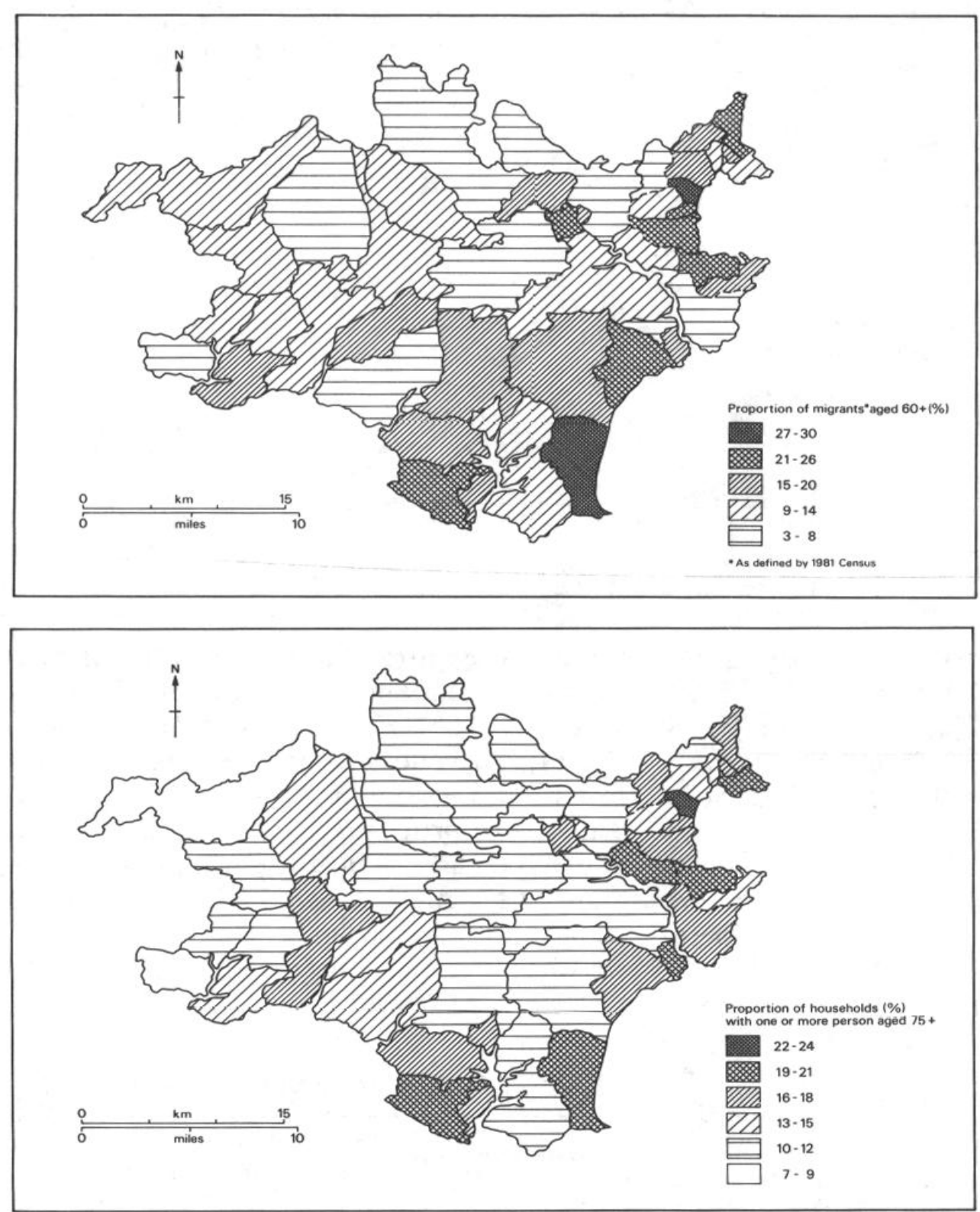

Figure 2.

Distribution of inmigrants during $1980-81$ aged $60+$ in South Hams and Torbay, 1981.
Figure 3.

Distribution of the very elderly $(75+)$ in South Hams and Torbay, 1981. elderly, particularly the over-75s, and in view of the widely-reported planning problems associated with the provision of housing and services for the elderly in both the urban and rural settlements of the area (South Hams District Council, 1986).

Some indication of the impact of the elderly in south Devon may be assessed by reference to Figures 1 to 3. It is clear from Figure 1 that the geographical distribution of the elderly is highly uneven at the parish or ward level. Very high proportions are found on the coast in the picturesque rural areas of Salcombe and Stokenham (see key Figure 5). Moreover, even these concentrations are exceeded in parts of Torbay such as Furzeham and Hollicombe. Inland, the density of the elderly population falls rapidly, although it should be noted that even the lowest choropleth category on Figure 2 indicates areas where the proportion of households with one or more pensioners exceeds 30 percent.

The pattern of migration reinforces these spatial trends (Figure 2). Once again the coastal estuarine zones, plus parts of Torbay including Hollicombe ward, exhibit very high levels of elderly immigration. The more popular retirement migrant destinations are associated with those areas containing the highest proportions of the elderly. If this trend were to continue, a danger is perceived locally of creating "geriatric ghettoes" (Torbay Planning Department, 1983). The response of the planning authorities to the incipient deve- 


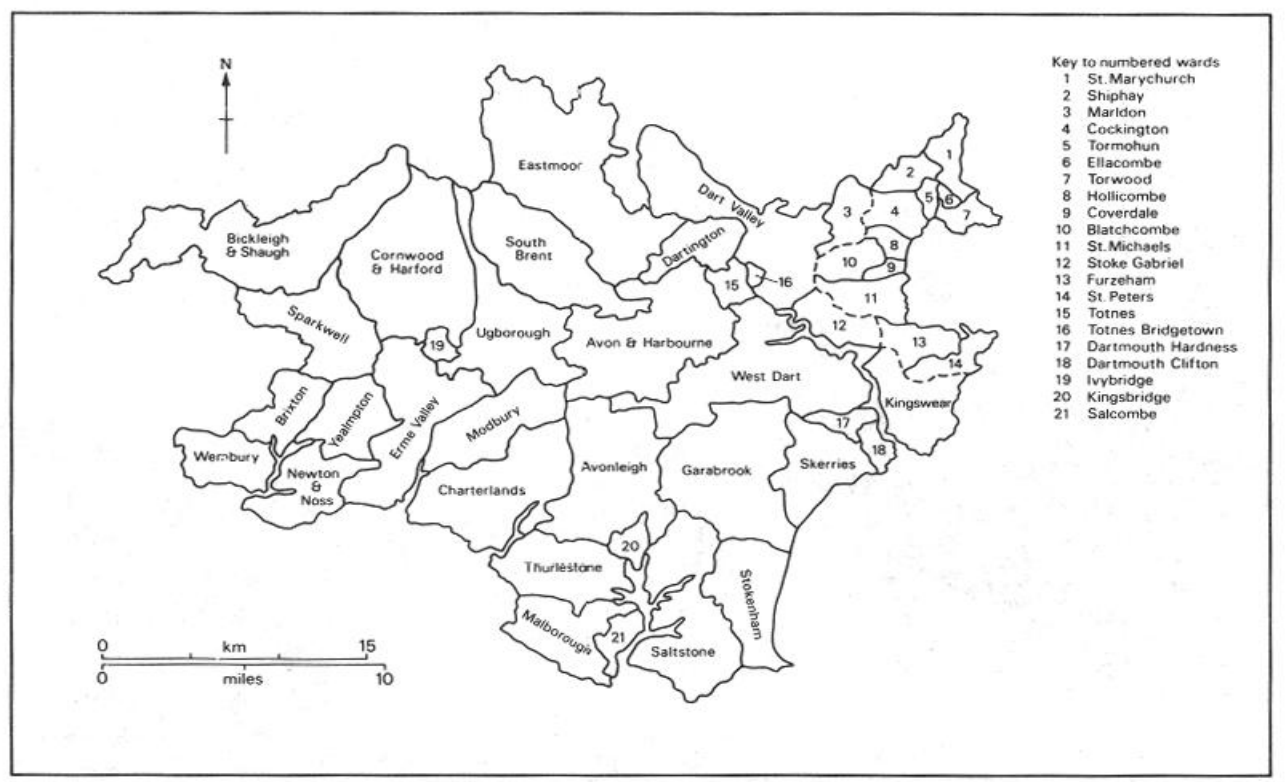

Figure 5. Location (key) map to wards of the Districts of South Hams and Torbay.

lopment of this phenomenon is discussed in a later section of this paper.

The spatial pattern of the aged $75+$ years population clearly reinforces the importance of the favoured coastal locations (Figure 3). It is of interest to note that, just as at the District scale nationally, the areas that are popular for retirees in general are the same areas occupied by the older elderly group (Warnes and Law, 1984). There is little evidence to indicate a process of spatial dissociation of the elderly according to age. The highest proportions of the over-75s are found in Hollicombe ward, Torbay CD, where they account for nearly one quarter of all usually resident households. There is a marked distance decay effect away from the coast, although even in the inland areas the lowest mapped categories of the very elderly population still represent a sizeable proportion of the total.

The housing market in south Devon South Devon is an area of relatively good quality housing, the majority of which is in owner-occupation (table 1). Very few households live in overcrowded conditions: indeed, the more common problem is one of underoccupancy (South Hams District Council, 1986). House prices tend to reflect. the attractiveness of the region for both retired and economically active groups. An analysis of property prices in south Devon showed clearly that house prices in all sections of the market were higher than in the adjacent major urban centre of Plymouth, in some instances markedly so. (table 2) (Western Morning News, 1986).

Table 2. House price variations in Devon

\begin{tabular}{|l|c|c|}
\hline House type & $\begin{array}{c}\text { Plymouth } \\
\text { area } \\
(£)\end{array}$ & $\begin{array}{c}\text { South } \\
\text { Hams } \\
(£)\end{array}$ \\
\hline $\begin{array}{l}\text { Two-bed flat/mai- } \\
\text { sonnette }\end{array}$ & 25500 & 31000 \\
Three-bed semi- & 24000 & 33500 \\
detached & 40000 & 54000 \\
Three-bed detached & 43000 & 49500 \\
\hline
\end{tabular}

Source: Western Morning News, 20th March 1986

In the rural areas of south Devon, much recent building has taken, the form of speculative, private bungalow estate develop-

Table 1. Housing tenure and amenities in South Devon, 1981 (percentages)

\begin{tabular}{|l|c|c|c|c|c|}
\hline & $\begin{array}{c}\text { Owner } \\
\text { occupied }\end{array}$ & $\begin{array}{c}\text { Council } \\
\text { rented }\end{array}$ & $\begin{array}{c}\text { Private } \\
\text { rented }\end{array}$ & $\begin{array}{c}\text { Sher/lack } \\
\text { bath }\end{array}$ & $\begin{array}{c}\text { >1 persons } \\
\text { per room }\end{array}$ \\
\hline SOUTH HAMS & 64 & 19 & 17 & 2 & 2 \\
TORBAY & 73 & 11 & 16 & 4 & 2 \\
\hline
\end{tabular}

Source: 1981 Census 
ment. These estates are commonly found on the periphery of the larger villages, although in some cases they are situated in semi-greenfield locations apparently unrelated to the existing settlement structure. Local Authority provision has been smallscale and certainly insufficient to reduce waiting lists (Phillips and Williams, 1982). Housing Associations have been active in the larger settlements, but again the volume of building is small and has failed to fill the vacuum created by shortfalls in the public sector (Richmond, 1983).

Within existing settlements, particularly the larger urban centres, there have been important changes in the structure of the housing market as a result of a large number of conversions of older, substantial properties dating from the Edwardian or late-Victorian period into individual accommodation units for the elderly. In addition, some inner-urban sites have been completely redeveloped, usually to provide purpose-built sheltered housing for sale or lease. The rapid development of purposebuilt and general accommodation for the elderly by the private sector has led to a number of critical problems for the planning authorities and for those providing services to the elderly (Phillips and Vincent, 1986). It is to the role of these public sector agencies that this paper will now turn.

\section{THE PLANNING BACKGROUND TO HOUSING PROVISION FOR THE ELDERLY}

Within Devon, there exist a number of authorities who have some interest in the provision of accommodation for the elderly. The Devon County Council has overall responsibility for planning policies (Devon Country Council, 1979; 1983). The County Council is also responsible for the social services, which inspect and register residential homes for the elderly and provide other domiciliary support services, such as home helps and meals on wheels. At the local level, Torbay CD and South Hams CD are two of ten country districts of Devon which are directly responsible through their planning and housing departments for the control of new development, planning applications and housing provision. This provision necessitates some liaison with both the social services and the health services. These three bodies have separate but overlapping areas of responsibility; collaboration can be effective but is made more difficult by the mismatch of spatial boundaries between the various authorities, and by the division of responsibility between the various services and the different levels of the administrative hierarchy.

Since 1974, the district councils have had a legal obligation to provide "statutory local plans", which set out the policies and proposals which the council intends to pursue over a period of about ten years. However, in non-metropolitan areas these have been published slowly and patchily. The South Hams CD in 1985 and 1986 produced a series of local plans to encompass the whole district, whereas Torbay $C D$ has not yet even reached the stage of public consultation. The delay in the publication of planning policies has been a contributory factor to the relative freedom experienced by developers in recent years.

In both districts, the provision of accomodation for the elderly is perceived as a problem. The South Hams CD is deemed to be an "area under pressure", because as an attractive area it receives many tourists and "is also very popular for retirement and second homes"' (South Hams District Council, 1986, 6). Local communities in the South Hams rated amongst their most serious problems; "too many retired people", "the number of elderly residents", "young people leaving the area", and "a shortfall of houses to buy and rent at prices locals can afford" (South Hams District Council, 1982, 3). Thus the major problem is seen tho be that elderly newcomers are depriving local young people of houses by inflating prices. Within Torbay, however, the issue is rather one of conversions of large houses into specialist accommodation for the elderly, forming distinctive zones within the urban fabric. This type of provision is to be found in the same areas as hotels and guest houses for the tourist trade, yet old people's homes seek relative 
quiet and security, while holiday makers are likely to bring noise and exuberant activity. In this way, "on balance the two uses are not entirely compatible even though they seek similar advantages in their location". The problem in Torbay is one of the formation of "geriatric ghettoes", in competition with the established and lucrative tourist trade (Torbay Planning Department, 1983).

Given the different perceptions of the influx of elderly people and the variety of housing that is potentially available, it is not surprising that local housing policies and the patterns of provision show marked variation. The potential housing provision falls into three broad categories. First and foremost, the private sector caters for owner-occupiers; retirement migrants may either buy existing dwellings or occupy newly constructed buildings, particularly bungalows. The district councils cannot restrict migrants buying existing housing, but have some control over new development either by refusing planning permission or by attaching conditions to building plans. In practice, until the recent publication of statutory plans in the South Hams and in the built-up areas, it has been possible to obtain planning permission for this type of venture. In the 1970s, housebuilding in the South Hams was intense, with a 23 percent increase in the total number of dwellings, of which approximately 85 percent were constructed by the private sector. From the mid-1980s, there are likely to be more restrictions on speculative building, particularly in the designated "Area of Outstanding Natural Beauty", the Coastal Protection Area, and in agricultural areas which lack residential infrastructure. The County Council policy, followed by the district councils will be "normally not to permit the construction of new houses or other development in rural areas outside towns or villages" (South Hams District Council, 1986). Some infilling will be permissible in the existing villages and towns, particularly in the larger settlements designated as "area centres" such as Totnes or Kingsbridge, or in "selected local centres" such as Salcombe or Stokenham.

The second main category of housing provision for the elderly is provided directly by the district councils which have a responsibility to meet the housing needs of their local populations. This requirement has conventionally been fulfilled by the provision of specially designed bungalows or flats or of sheltered accommodation for rent. The housing policy in the South Hams $\mathrm{CD}$ to meet local housing needs is constrained by financial stringency. The council considers that housing needs can be met most effectively by providing housing units for the elderly, "given the high number of elderly persons on the waiting list" (South Hams District Council, 1986b, 38.2) which would release larger housing units for local families. The South Hams CD is therefore providing major sheltered projects in the larger towns of Totnes and Dartmouth, and smaller groups of flats and bungalows in villages where there is a clear need and where development can be in keeping with the character of the village. The council is also increasingly involved in unconventional forms of housing provision, and they have an active policy of supporting "housing associations and private developers to concentrate their activities in providing accommodation of the appropriate tenure in the locations of greatest need". It feels that the provision of local authority housing of whatever tenure is "particularly important in "retirement"' areas where prices are high"' (South Hams District Council, 1986b, 38.7). There are therefore a substantial number of special units for the elderly run by both Torbay and South Hams CD but they are insufficient to meet demand (Richmond, 1983; Phillips and Williams, 1982).

The third major element in the housing stock is the provision of privately owned and managed accommodation in retirement homes, nursing homes and, increasingly, in leasehold or owner-occupied sheltered accommodation. This accommodation is in large multiple units, with continuous wardening or nursing care, and caters largely for the very elderly and infirm. This type of accommodation can again be controlled by the district councils, who can refuse planning permission for the construction of new developments or the conversion of existing properties. Furthermore, the establishment of private 
Figure 4. Distribution of old persons' accommodation and location of areas of planning controls in Torbay, 1986.

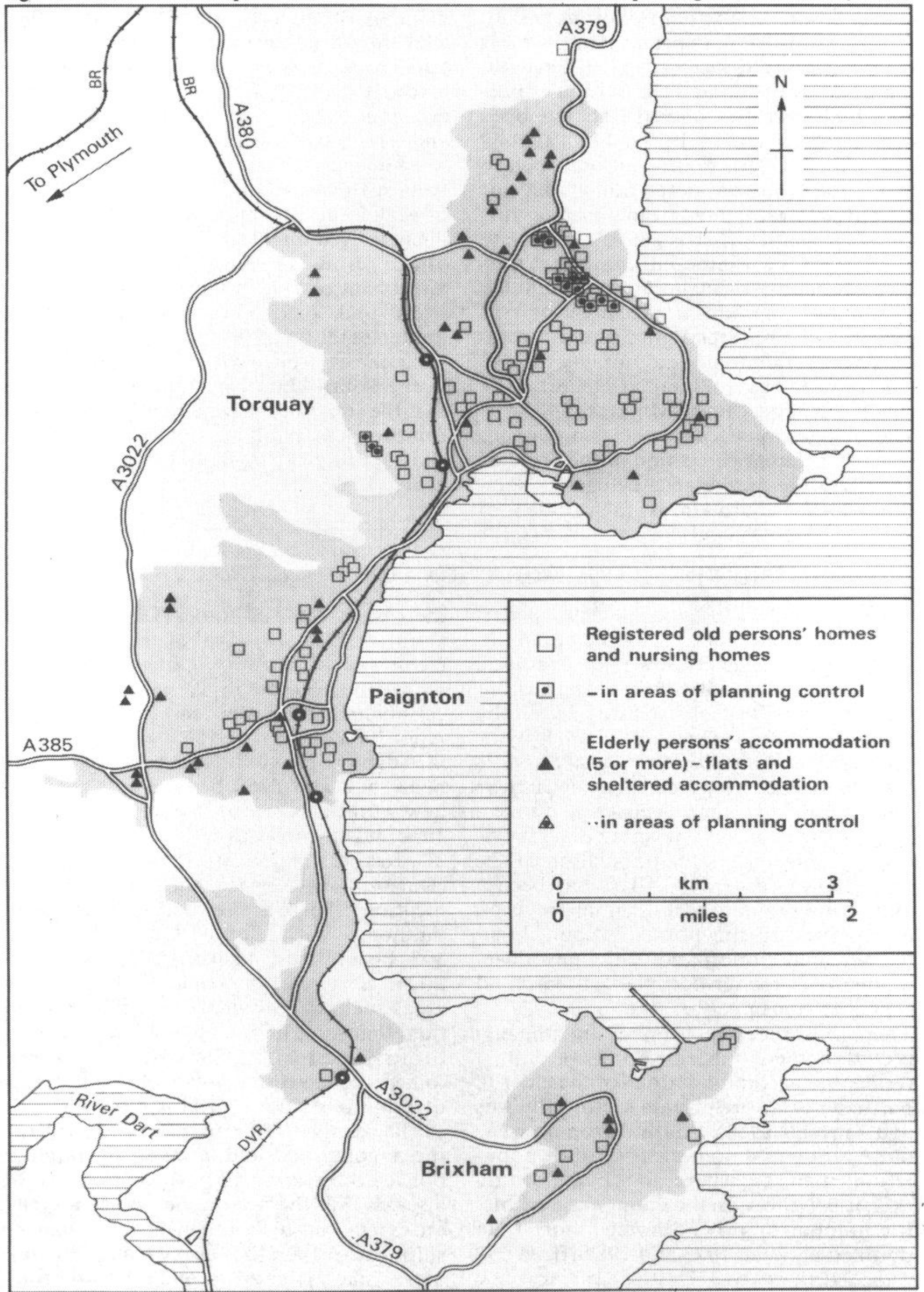

Source: Torbay Planning Departement. 
residential homes is controlled by the social services, who require homes for more than three persons to be registered and subject to inspection. The increase in registered old peoples' homes and in the provision of purpose built privately owned flats has been a particular concern in Torbay. Torbay have examined the policy options open to them, and have considered that a policy of selective restraint must be imposed on further development. Changes of land use to old persons' accommodation will not normally be allowed in the areas of holiday accommodation, nor in three areas of Torquay where are already major concentrations of residential and nursing homes (figure 4) (Torbay Planning Department, 1983; Torbay Council Minutes, 1986).

The policies adopted by the two councils reveal a different perception of the problem and therefore they advocate different solutions. In the South Hams, the problem of wealthy retirement migrants increasing the value of the housing stock has led to the adoption of policies geared particularly to poorer pensioners and to local people affected by the rise in house prices. The decision to encourage a variety of builders and tenure patterns may be seen also as an attempt to widen the type of housing available in the area. In Torbay, the creation of very large retirement communities and the perceived threat to the tourist provision of the resort is being met by much more direct control over further property conversions and developments. The belated implementation of these development control policies (from 1983 in Torbay and 1986 in the South Hams) has meant, however, that the supply of private housing designed for the elderly has been able to increase substantially throughout the past twenty years.

\section{THE PROVISION OF ACCOMMODATION FOR THE ELDERLY}

Since the mid 1970s, the specialist provision of accommodation for the elderly in south Devon has shown a dramatic increase. The majority of the elderly within the area are still accommodated within the normal housing stock, and it is the policy of Devon County Council Social Services Departement to keep elderly people in their own homes for as long as possible, if necessary by the provision of domiciliary services. Nonetheless, as the population of the very elderly has grown, there has been a major extension of the residential provision in registered nursing homes, in council rented accommodation and in the new developments of owner-occupied or leasehold sheltered housing.

There has recently been a phenomenal growth in the number of homes providing residential accommodation for the elderly, particularly in the private sector (Phillips and Vincent, 1986). South Devon now has more residential homes per head of population than anywhere in Great Britain except Brighton. In the county as a whole, the number of private homes more than doubled between 1975 and 1983, from 152 with 2342 places to 377 with 2825 places: the increase in beds was more modest. By 1986 there were over 500 homes (Devon County Council, 1985, 70). Torbay itself, the centre of this private development, contained more private homes by 1986 than the whole county had had eleven years previously. By April 1986, there were 155 registered homes in Torbay, providing between 4 and 50 beds each and 2363 beds in total. Three new homes were due for registration in June and 16 applications for extensions and 27 further registrations were pending (Devon Social Services, personal communication). There are fewer private residential homes in the South Hams ( 28 homes, 392 beds). Informal opinion from the Social Services Department suggests that areas such as Torbay are reaching saturation, that some homes are not full, and that to attract custom the new homes are having to become increasingly specialised, perhaps offering particular types of medical care, as the relatively fit and active stay within the community and their own homes, bolstered by domiciliary social services. It appears that the new homes are to a greater extent run by companies and partnerships rather than the family team that was more usual in the 1970s, and are correspondingly larger and more impersonal. 


\section{5}

The provision of council residential homes for the elderly has, by contrast, remained virtually static, with about 2300 places in the county. In council homes, the average age of the occupants is about 83 , and 35 percent or over had severe difficulties with mobility, incontinence or mental confusion (Devon County Council, 1985, 71). Council provision in wardened accommodation is available in both Torbay and the South Hams, providing over 400 beds in each district. These units may consist of flats or bungalows, either linked to a central alarm system or with a resident warden on site. Increasingly, the councils are participating in developments other than the strenghtforward building of council property for rent, for example in partnership with housing associations or with private developers who may agree to house people from the council waiting list. Within Torbay, seven housing associations have provided 18 developments, almost all of which are flats or sheltered accommodation for old people.

A major innovation of the last ten years has been the development by major construction companies such as Wimpey, Marwood, and McCarthy and Stone of owner-occupied or leasehold apartments in blocks of specially constructed sheltered housing. Within Torquay, there are two McCarthy and Stone developments with 62 flats, a similar development by another Bournemouth-based company of 59 flats, and three other leasehold developments of the same type. Such provision has not been developed within the South Hams but is of increasing significance within the traditional resort retirement zones.

The role of private-sector provision: an example of sheltered housing for the elderly The demands made by the high and increasing numbers of the elderly in south Devon have arguably stimulated a response by both the private and public housing sectors. At a time of financial stringency and during a period when the prevailing political ideology has favoured the private sector, the housing made by the public sector has been limited. The response has therefore principally been private sector initiatives which have increased the supply and the range of accomodation suitable for the elderly. Such as explanation accords well with the role attributed to consumer sovereignty in free market economics. Despite the superficial applicability of a classical market framework of explanation, it is doubtful whether it represents the true causal mechanisms. Private companies play more than a passive, reactive role determined by consumer demand.

An alternative explanation is that the changing geography of the elderly is not entirely demand-led but is determined to an extent by the autonomous activities of the speculative developers engaged in housing provision. In short, the process may be supply-led rather demand-induced. This approach would shift the locus of power away from the consumer to the developer whose actions will detemine where and to what extent those of pensionable age will be encouraged to locate. Notions of consumer sovereignty then become of secondary importance to the role of private developers who, as the most powerful agencies involved, will be the primary determinants of change.

Evidence to support this supply-led hypothesis may be found in the activities of the major UK builder and developer of warden-assisted sheltered housing in the private sector: McCarty and Stone plc. This company has grown rapidly since pioneering the concept of private sector sheltered accommodation in the mid-1970s. More than 70 schemes have been completed to date and an ambitious expansion scheme is being pursued in many of the retirement areas of Britain and abroad. A recent development in Devon is the $£ 1.5$ million 'Homemeadows House' scheme in Sidmouth which will provide 43 'selfcontained, safe and secure' retirement homes (Western Morning News, 22.3.86). An indication of the success of the company is their recent statement of profits (The Times, 17.5.86) for the half year to April 1986 which showed an increase of 23 percent to $£ 5$ millions.

The corporate strategy of McCarthy and Stone plc provides an insight into the importance of supply-side influences determining the residential location of the elderly. Holland (1986) has suggested that the company searches speculatively for building plots within broadly defined reti- 
rement areas such as the Scarborough area, south Hampshire and south Devon. The selection of sites is crucial since it is deemed essential that all sheltered housing schemes must be within a level half mile of shops, on a bus route, and not as in some earlier similar schemes greenfield sites on the rural-urban fringe. The site selection process is clearly in accordance with the Departement of Health and Social Security's (DHSS) guidelines on the provision of accommodation for the elderly.

Having selected a site, the company undertakes a feasibility study which assesses the number of potential customers by reference to its location and the social and demographic characteristics of the elderly population within a certain distance of the proposed development. Since approximately 80 percent of all purchasers of sheltered units are from the local area, and since the company knows the number of elderly people required to sell a unit, the required population is compared with the actual population in the scheme's catchment. On this basis, a decision is made whether or not the scheme is likely to be sufficiently profitable. Once a positive decision has been made, a vigorous local marketing campaign is undertaken to sell the advantages of the McCarthy and Stone lifestyle based on the appeal of security, safety and minimal maintenance.

Two important points need to be made concerning this strategy. First, the only sites that are investigated are those within already established retirement zones. This will clearly serve to accelerate the growth of existing retirement areas, particularly in respect of the over-75s. The company's argument that such provision does not increase the numbers of elderly because 80 percent are drawn locally overlooks the point that halting outmovement is just as effective a means of raising the proportion of the elderly as promoting inmovement. The second point arising from the company's decision-making process is the relatively unconstrained role of the private sector in determining the future location of the elderly. According to Holland (1986) the sheltered housing schemes built in the late 1970 s by McCarthy and Stone were 'a construction-led development of the market' (emphasis added). That this development met little opposition from the planning system has already been commented upon: what seems clear is the important if not dominant role played by the private developer in shaping the future residential geography of one sector of the elderly. Although this is only one example drawn from a particular field of provision, it is difficult to escape the conclusion that other developers will probably behave in the same manner in respect of their particular sectors of the market. Clearly, much further research is needed to substantiate the extent to which the provision of housing determines the location of the elderly and very elderly populations. The evidence presented here suggests that, at the very least, such a possibility deserves more careful consideration than has been apparent in the literature to date. A focus on the activities of producers of an emerging geography of the elderly rather than on the consumers is urgently required.

\section{DISCUSSION AND CONCLUSIONS}

Torbay is a traditional resort area which has experienced retirement migration over a number of decades, while the South Hams, a more rural and inland arca, has gained its retirement population predominantly since 1970 . The two districts are therefore at different stages in the development of provision for the elderly. In the South Hams, large numbers of houses were built during the 1970 s. In many cases these dwellings were burigalows or easily-managed detached houses aimed at the relatively wealthy retirement or preretirement market. The resulting influx of elderly people is now perceived as a problem, because of the inflation of house prices and the shortage of housing provision for the local population. The significant issue is how this problem, as it is perceived, was allowed to occur. It is clear that the majority of housing has been provided by the private sector, and as such its deve- 
lopment could have been curtailed by the District Council refusing planning permission for new development. In the period before the publication of the statutory local plans, however, this control was not stringently applied, and those developers submitting planning applications which conformed to the overall regulations were unlikely to have been refused. The South Hams DC clearly recognise this to have been the case:

'Planning has a considerable influence on in-migration through the allocation of residential development land. High rates of in-migration in the past are the result of the take-up of sizeable development land allocations in the old Outline Development Plans'.

(South Hams District Council, 1986b, 2.1)

Within the South Hams, therefore, the inmigration of the elderly in the 1970 s can be seen to have been a response to the development of a supply of suitable housing by the private sector which took advantage of the weak planning controls. The problem now facing the South Hams as a housing authority is the mismatch of the family housing they have available with the increasing needs of one or two person households. Furthermore, as the elderly population becomes older, less mobile and in need of greater help from the social and health services, the South Hams will begin to face the same problems that are now evident in Torbay.

Torbay is at a later stage: its elderly population is no longer increasing but it is becoming increasingly elderly, infirm and in need of specialist and sheltered accommodation. It is for this reason that the supply of private residential accommodation and of privately-owned sheltered housing has mushroomed in the last ten years. Both of these forms of accomodation are filling the gap which arises from inadequate and under-financed council accommodation. Both are catering for a market of elderly people who are in situ and who, for a variety of reasons, are no longer capable of running their own homes. They are therefore providing residential accommodation for a second-retirement move; they are obviously attracted to areas such as Torbay where there is a large captive market. In the case of private sheltered accommodation, such as that provided by McCarthy and Stone, the market consists of home-owners who are able to buy their sheltered flat outright. Private nursing and residential homes cater for those who are more infirm; their residents are able to claim fees allowances from the DHSS of about $£ 130$ per week, which usually is paid directly to the home. The private sector is therefore supplying an essential need, that of sheltered housing for the very elderly, which the councils are unable to supply. It is undoubtedly true that the concentration of the problem would not have occured to such a great extent if planning controls had been more effectively applied in earlier decades.

Within south Devon there has long been a demand for retirement homes in this pleasant, mild, seaside area. Its increasing concentration of the elderly has not, however, been genuinely demand-led but has been facilitated by private housing development which has taken advantage of lax planning constraints. The private sector in Torbay is now also providing second retirement homes in sheltered or nursing accommodation for the large number of very elderly residents. Increasing control over planning applications for private house building in the South Hams may reduce its problems in the future. But in Torbay planning controls over new pirate residential homes without the provision of adequate alternative public sector accommodation, could compound the problem brought about by relatively uncontrolled residential development: in so doing they could penalise one of the most vulnerable sections of society.

\section{REFERENCES}

Devon County Council (1979) Devon County Structure Plan Devon CC, Exeter

Devon County (1983) Devon County Structure Plan: First Alteration Devon CC, Exeter
Devon County Council (1985) Devon in Figures Devon CC, Exeter

District of Torbay (1986) Minute 1523/2/86 Council Minutes 
Holland, K. (1986) The Provision of Sheltered Housing for the Elderly: the contribution of McCarthy and Stone. Paper presented to Regional Studies Association Conference, Dorset Inst of Higher Education.

Law, C. and Warnes, A. (1976) The changing geography of the elderly in England and Wales. Trans. Inst. Brit. Geog. N.S.1, 453-71

Phillips, D. and Williams, A. (1982) Local Authority housing and accessibility: some evidence from the South Hams, Devon, Trans. Inst. Brit. Geogr. N.S.7, 304-20

Phillips, D.R. and Vincent J.A. (1986) Petit Bourgeois, care: Private residential case for the elderly. Policy and Politics 14, 2, 189-208

Richmond, P. (1983) Housing associations in rural areas. S. $W$. Papers in Geography No 7 Plymouth Polytechnic/Exeter University

South Hams District Council (1982) Community Appraisals: The Local Response SHDC
South Hams District Council (1986) Kingsbrigde Local Plan SHDC

South Hams District Council (1986b) Planning Policies: Practice and Programmes 2 vols. SHDC.

Taylor, H. and Todd, H. (1982) 'British research on social gerontology and its relevance to policy: towards a geographical contribution' in Warnes, A.M. (ed) Geographical Perspectives on the Elderly Chichester: Wiley

Torbay Planning Department (1983) Elderly Persons' Accommodation in Torbay T.P.D.

Warnes, A. and Law, C. (1984) The elderly population of Great Britain. Trans. Inst. Brit. Geogr. 9, 1, 37-57.

Western Morning News (1986) S.W. property market analysis. 20th March 1986. 